\title{
MULTIKRITERIÁLNÍ HODNOCENÍ ROZVOJOVÝCH LOKALIT NA ZÁKLADĚ KVALITY HROMADNÉ DOPRAVY
}

\author{
MULTI-CRITERIA RATING OF DEVELOPMENT AREAS BASED ON \\ PUBLIC TRANSPORT QUALITY
}

\author{
Dmitrii Grishchuk ${ }^{* 1}$, Pavel Stupka**1
}

"grishchuk.dmitrii@kambrno.cz, ${ }^{* *}$ stupka.pavel@kambrno.cz

${ }^{1}$ Vysoké učení technické v Brně, Fakulta stavební, Veveři 331/95, 60200 Brno

\begin{abstract}
Abstrakt
Při plánování území u oblasti, jež čeká významná proměna, je třeba se zamýšlet nad obsluhou veřejnou dopravu, zejména ve velkých městech. V podmínkách omezených rozpočtů má smysl navrhovat zástavbu v první řadě v lokalitách, které již jsou napojeny na stávající linky MHD, nebo kde se obsluha dá rychle, kvalitně a levně zajistit. S kvalitní hromadnou dopravou by obyvatelé města aktivněji ji volili, a přispívali tím ke zlepšení kvality životního prostředí. Autoři proto vytvořili multikriteriální analýzu, která hodnotí rozvojové lokality z hlediska dostupnosti a kvality hromadné dopravy na základě objektivních dat. Jako př́klad implementace analýzy bylo zvoleno město Brno, které chystá nový uzemní plán.
\end{abstract}

\section{Klíčová slova}

Územní plánování, hromadná doprava, GIS, programování, jízdní řády

\begin{abstract}
When planning territories, public transport has to be considered in areas that are undergoing a major transformation, especially in large cities. In conditions of limited budgets, it makes sense to primarily develop areas already connected to existing public transport network, or where the service can be provided quickly, efficiently and at low cost. With quality public transport, city residents would prefer it over cars and contribute to improving the environment. That led authors to creation of a multi-criteria analysis that appraises development areas in terms of availability and quality of public transport using objective data. Brno city, which issues a new masterplan soon, was chosen to demonstrate the implementation of the analysis.
\end{abstract}

\section{Key words}

Spatial planning, public transport, GIS, programming, timetables

\section{1 ÚVOD}

Města se neustále potkávají s problémy a výzvami spojenými s dopravou, především ekonomické a ekologické povahy. Na stavu dopravních záležitostí závisí i udržitelnost města jako celku. Nejlogičtější cestou řešení obsluhy nově vznikajících lokalit hromadnou dopravou (rozsah, směry) je její plánování již na úrovní úvah o těchto lokalitách. Obsluha by měla být v dostateční míře frekventovaná a správně trasována, tedy má vést k hlavním bodům zájmu lidí z navrhované lokality z co nejmenšími časovými ztrátami. Pomohlo by to zachovat rozumnou dělbu přepravní práce (poměr MHD/IAD/jiné), zejména v hustě zalidněných sídelních prvcích.

Analýza obsluhy rozvojových lokalit systémem MHD se dá rozdělit do dvou hladin - ekonomické a uživatelské. První se týká objednatelů obsluhy (stát, kraj, město) a zabývá se kapitálovými a provozními náklady - na pořízení vozidel, výstavbu tratí a komunikací, výplaty zaměstnancům. Druhá zohledňuje uživatelskou zkušenost, na kterou se autoři rozhodli zaměřit. 


\section{POUŽITÍ MULTIKRITERIÁLNÍCH ANALÝZ}

O umístění staveb a zajištění MHD se, například, diskutuje v českém národním certifikačním nástroji SBToolCZ (jenž je derivátem mezinárodního systému SBTool) pro vyjádření úrovně komplexní kvality budov [1]. V ohled jsou brány pěší vzdálenosti do zastávek MHD, typ a stupeň ochrany komunikací pro pěší a frekventovanost linek. Nicméně body získané za tato kritéria neovlivňují celkové hodnocení budovy, které se zakládá především na environmentálních a sociálních faktorech; ekonomické a prostorové faktory slouží jen pro referenci, jako dodatečná.

Jsou také poměrně často hodnoceny samotné systémy hromadné dopravy. Někteří autoři posuzují efektivitu navrhovaných linek podle počtu potenciálně obsloužených obyvatel, celkové jízdní doby, dostupnosti železničních stanic [2]. Jiní hodnotí projekty systémů hromadné dopravy pomoci složitých hierarchických struktur, včetně ekonomických a provozních parametrů [3].

Doposud ale nebyly nalezeny publikace jiných autorů o použití multikriteriálního hodnocení lokalit výhradně na základě kvality hromadné dopravy v českém nebo mezinárodním vědeckém prostředí.

\section{Zkušenost autorů}

Autoři této práce se již v nedávné minulosti daným tématem zaobírali, a byla vytvořena první verze metodiky hodnocení rozvojových lokalit na základě dopravní obslužnosti. Mezi kritérii byla zařazena vzdálenost do nejbližší zastávky, cestovní doba do centra města, průměrné zpoždění ve špičkách, podíl nezpožděných spojů ve špičkách a celkový počet spojů přes nejbližší zastávku [4].

Po dalším prohloubení do problematiky se však ukázalo, že je vhodné doplnit metodiku o další parametr. V odborné literatuře se píše o zkresleném vnímaní času během přepravy v hromadné dopravě. Je stanoveno, že vnímaný cestujícím čas je o $11 \%$ větší než skutečný při čekání na spoje, a o 7-9 \% vetší při chůzi [5]. Tento faktor může mít vliv na dělbu přepravní práce v lokalitách; pokud je vnímaná cestovní doba vysoká, lidi si s vyšší pravděpodobností zvolí IAD pro cestu do nebo z dané lokality.

\section{METODIKA}

Bodový systém u kritérí byl zachován stejný jako v předchozí verzi metodiky [4]. Za každé kritérium mohla lokalita získat až 5 bodů, ale v nové verzi maximální součet bodů se rovna 30 vzhledem $\mathrm{k}$ jednomu přidanému kritériu - vlivu vnímané cestovní doby.

Tab. 1 Kritéria analýzy (dolní mez $<$ hodnota $\leq$ horní mez)

\begin{tabular}{ccccccc}
\hline Body & $\begin{array}{c}\text { Vzdálenost do } \\
\text { nejbližśi } \\
\text { zastávky, } \mathbf{m}\end{array}$ & $\begin{array}{c}\text { Čas do } \\
\text { centra, } \\
\text { minut }\end{array}$ & $\begin{array}{c}\text { Míra vlivu } \\
\text { vnímané } \\
\text { cestovní } \\
\text { doby, } \%\end{array}$ & $\begin{array}{c}\text { Průměrné } \\
\text { zpoždění na } \\
\text { nejbližší } \\
\text { zastávce, minut }\end{array}$ & $\begin{array}{c}\text { Podíl } \\
\text { nezpožděných } \\
\text { spojů přes } \\
\text { zastávku, } \%\end{array}$ & $\begin{array}{c}\text { Počet spojů } \\
\text { vracovní } \\
\text { den }\end{array}$ \\
\hline $\mathbf{5}$ & méně než 50 & $\begin{array}{c}\text { méně než } \\
5\end{array}$ & Méně než 1 & méně než 0,5 & více než 80 & více než 500 \\
$\mathbf{4}$ & $50-100$ & $5-10$ & $1-2$ & $0,5-1$ & $70-80$ & $300-500$ \\
$\mathbf{3}$ & $100-250$ & $10-20$ & $2-3$ & $1-2$ & $55-70$ & $150-300$ \\
$\mathbf{2}$ & $250-500$ & $20-30$ & $3-4$ & $2-3$ & $40-55$ & $100-150$ \\
$\mathbf{1}$ & $500-700$ & $30-40$ & $4-5$ & $3-4$ & $20-40$ & $50-100$ \\
$\mathbf{0}$ & více než 700 & více než & více než 5 & více než 4 & méně než 20 & méně než 25 \\
\hline
\end{tabular}

Vliv vnímané cestovní doby ukazuje, o kolik procent delší přijde cestujícímu celková cesta z centra do hranice lokality, než ve skutečnosti je. Uvažujme zde, že délka chůze z centra je nulová, protože předpoklad je, že cestující vyráží z jedné z centrálních zastávek, rychlost chůze od zastávky k lokalitě se rovná $5 \mathrm{~km} / \mathrm{h}$. Máme tedy vztah:

$$
k_{v}=\frac{\sum t_{\check{c}} \cdot k_{\check{c}}+\frac{d_{c h}}{v_{c h}} \cdot k_{c h}}{\sum t_{c}+\sum t_{\check{c}}+\frac{d_{c h}}{v_{c h}}} \cdot 100,
$$


kde $k_{v}$ - míra vlivu vnímané cestovní doby, \%; $\sum t_{c}$ - součet skutečných cestovních dob ke hranicím lokality, min.; $\sum t_{\check{c}}-$ součet čekacích dob, min.; $d_{c h}$ - délka pěšího přesunu od zastávky k lokalitě, m.; $v_{c h}-$ rychlost pěší chůze, $5 \mathrm{~km} / \mathrm{h}\left(83,3 \mathrm{~m} . / \mathrm{min}\right.$.); $k_{\check{c}}-$ koeficient vnímaní času čekání, 0,$11 ; k_{c h}-$ koeficient vnímaní času chůze, 0,08 .

Nízká míra vlivu vnímaného času znamená existenci př́mého spojení bez přestupů nebo s přestupy s minimálním čekáním při přestupu a krátké docházky. Čím vyšší je hodnota tohoto kritéria, tím větší je pravděpodobnost, že taková cesta odradí potenciálního cestujícího do lokality od hromadné dopravy.

Čas přestupů ale ve výsledcích předešlé verze metodiky nefiguroval a na rozdíl od doby pěšího přesunu nedal odhadnout nebo odvodit, proto byla nutná modifikace skriptu s algoritmem hledání nejkratší cesty (upravený Dijkstrův algoritmus pro časově závislé sítě) použitého v minulosti.

Po modifikaci skript při hledání cesty zachycoval místa a délky přestupů, pokud se měnilo číslo linky (Obr. 1).

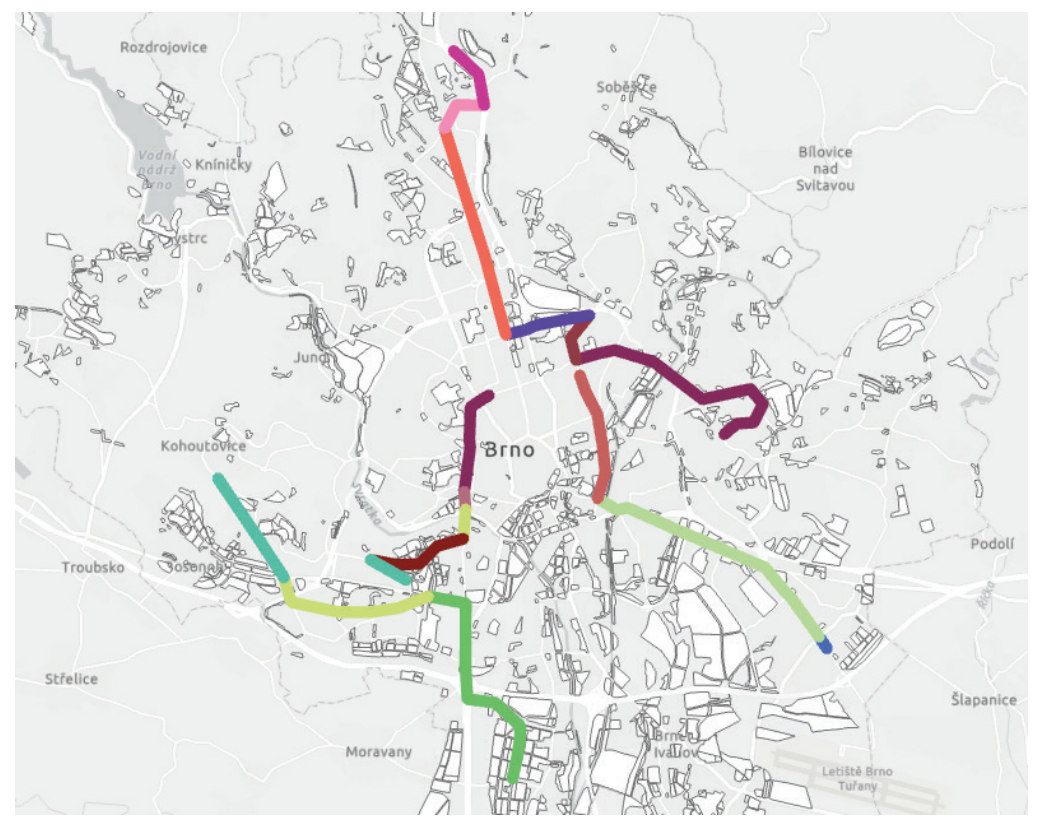

Obr. 1 Př́iklady nejkratších cest z vygenerovaných jízdních řádů.

Zároveň optimalizace kódu zrychlila proces zpracování a umožnila spustit skript nejen pro jeden čas "odjezdu", ale pro několik. Za kontrolní období byl zvolen interval od 7:00 do 7:18, bylo uskutečněno 10 "odjezdů" po 2 minutách, aby se eliminoval vliv intervalů nepáteřních méně frekventovaných linek při cestách na vzdálené okraje. Za výsledný čas nejrychlejší cesty byl pak považován průměr nejrychlejších cestovních dob. Průměr součtů čekacích dob byl násoben 0,11 , průměr doby pěší chůze (v tomto případě se jedná jen o vzdálenost od nejbližší zastávky do hranice lokality) byl násoben 0,08 , a dále podle vzorce (1).

\section{VÝSLEDKY}

Po obodování a sečtení bodů pro každou rozvojovou lokalitu byla vytvořena škála kategorii 1 až 10 . V čím nižší kategorii se rozvojová lokalita nachází, tím lepší je její obslužnost MHD (Tab. 2).

Tab. 2 Kategorie rozvojových oblastí v Brně (dolní mez < hodnota $\leq$ horní mez)

\begin{tabular}{cccc}
\hline Kategorie & Meze (součet bodů) & $\begin{array}{c}\text { Počet rozvojových } \\
\text { lokalit }\end{array}$ & $\begin{array}{c}\text { Podíl } \\
\%\end{array}$ \\
\hline $\mathbf{1 0}$ & $0-3$ & 13 & 1,0 \\
$\mathbf{9}$ & $3-6$ & 6 & 0,5 \\
$\mathbf{8}$ & $6-9$ & 13 & 1,0 \\
\hline
\end{tabular}




\begin{tabular}{cccc}
$\mathbf{7}$ & $9-12$ & 16 & 1,2 \\
$\mathbf{6}$ & $12-15$ & 106 & 8,0 \\
$\mathbf{5}$ & $15-18$ & 291 & 21,9 \\
$\mathbf{4}$ & $18-21$ & 419 & 31,6 \\
$\mathbf{3}$ & $21-24$ & 341 & 25,7 \\
$\mathbf{2}$ & $24-27$ & 65 & 4,9 \\
$\mathbf{1}$ & $27-30$ & 58 & 4,4 \\
\hline
\end{tabular}

Na mapě města Brna (Obr. 2) je znázorněno barevné rozdělení lokalit dle škály kategorií. Z mapy lze vyčíst, že lokality v blízkosti centra města spadají do nižších kategorií, hlavním důvodem je hustá sít MHD kolem centra. S rostoucí vzdáleností od centra začínají rozvojové lokality spadat do vyšších kategorií, kdy strávený čas v MHD už pro obyvatele není komfortní a je větší pravděpodobnost, že lidé budou pro cestu používat osobní automobil.

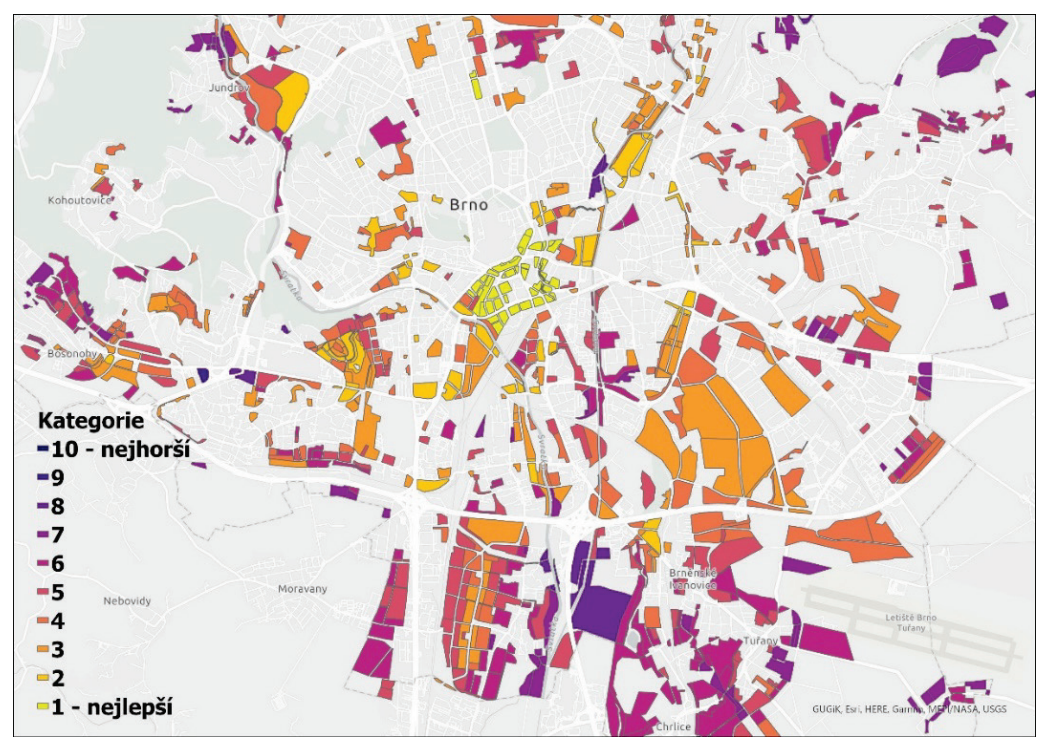

Obr. 2 Mapové zobrazení kategorií rozvojových oblastí v Brně.

\section{DISKUZE}

Nově přidané kritérium - míra vlivu vnímaného cestovního času - je důležitý parametr, ale výpočet jak nejrychlejších cestovních, tak i čekacích dob může být vylepšen, pokud se zohlední minimální časová mezera potřebná $\mathrm{k}$ přestupu $\mathrm{v}$ jednoduchých generovaných jízdních řádech. $\mathrm{Z}$ důvodu použití takových jízdních řádů u zastávek bylo pouze jedno nástupiště bez ohledu na jejích významnost (tzn. přesun v rámci stejné zastávky byl vyloučen). Docházelo tak k intenzivnímu přestupování mezi linkami, i když časová mezera mezi př́ijezdem jedné linky a odjezdem druhé se rovnala $1 \mathrm{~s}$.

Kvůli tomu, že hodně lokalit za toto kritérium získalo vysoké hodnocení, průměrné celkové hodnocení se zvýšilo oproti první verzi metodiky. O vhodnosti zvolených mezí kritérií ale vypovídá to, že rozdělení skóre lokalit je pořád blízké k normálnímu (Obr. 3). Očekává se, že po eliminaci nerealisticky krátkých přestupů se průměr změní na hodnotu v okolí 17,5 bodů. 


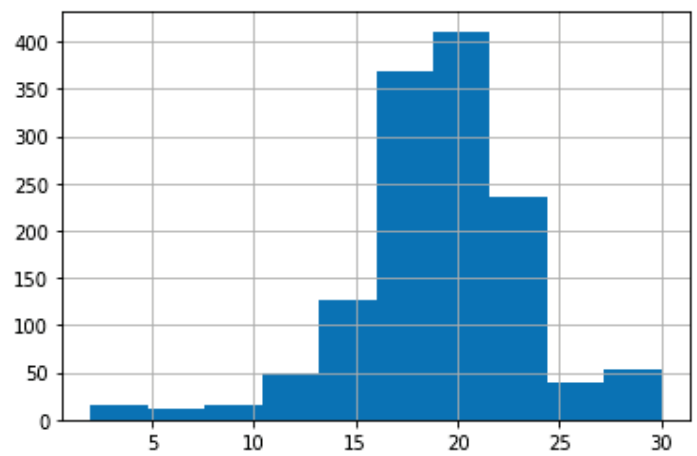

Obr. 3 Histogram skóre rozvojových lokalit (horiz. osa - body, vertik. osa - počet výskytů).

\section{ZÁVĚR}

Tato analýza díky své jednoduchosti a přehlednosti má potenciál se zařadit mezi odborné nástroje pro státní a municipální instituce při navrhování územních plánu, nebo pro developery hledající nejvhodnější lokalitu na umístění svého projektu.

V tomto př́spěvku byla aplikována analýza na připravovaný uzemní plán města Brna, jelikož se ale jedná o plně automatizovaný proces s použitím podkladů v univerzálních rožšriřených formátech, je možné při správném nastavení dat použít postup na jakékoliv území.

\section{Poděkování}

Článek byl vytvořen za podpory projektu Specifického výzkumu FAST-J-21-7518 Chytré územní a dopravní plánování rozvojových lokalit.

\section{Použité zdroje}

[1] VONKA M. a kol. Metodika SBToolCZ - Manuál hodnocení bytových staveb ve fázi návrhu. Praha, 2010. ISBN 978-80-01-04664-7.

[2] KRAKOWIAK-BAL A., LASOCKA T., SALAMON J., FINDURA P.. The use of multiple-criteria ranking methods for designing public transport systems. Infrastructure and Ecology of Rural Areas. IV. 2014.

[3] ZAK Jacek, FIEREK Szymon, KRUSZYŃSKI Mirosław, ZMUDA-TRZEBIATOWSKI Pawel. Multiple Level, Multiple Criteria Ranking of Transportation Projects. Conference: 13th World Conference on Transport Reseach (WCTR), Rio de Janeiro, DOI:10.13140/2.1.4826.2726.

[4] VŠETEČKA Martin, STUPKA Pavel. GRISHCHUK Dmitrii. Chytré územní a dopravní plánování rozvojových lokalit, Zborník Verejná osobná doprava 2021, Kongres STUDIO, spol. s r. o., 2021, ISBN 978-80-89565-49-8

[5] MENG M., RAU A., MAHARDHIKA H.: Public transport travel time perception: Effects of socioeconomic characteristics, trip characteristics and facility usage. Transportation Research Part A: Policy and Practice, Volume 114, Part A, 2018, ISSN 0965-8564, https://doi.org/10.1016/j.tra.2018.01.015. 